\title{
Pengaruh Kompetensi, Kompensasi Dan Motivasi Terhadap Kinerja Guru PNS Bersertifikasi pada SMP Negeri 7 palembang
}

\author{
Yuniarti
}

Published online: 5 December 2021

\begin{abstract}
This study aims to determine the effect of Competence, Compensation and Motivation on the Performance of Certified Teachers in SMP Negeri 7 Palembang. In this study, the sample taken was all teachers with the status of Certified Civil Servants, totalling 40 people as samples of trial data and research data. In this study, the sampling technique is done by using the saturated sampling technique that is all populations are sampled regression equations. From the results of this study, there is a positive and significant influence simultaneously Competency, Compensation and Motivation on the Performance of Certified Civil Servants Teachers in Palembang 7 Public Middle School, which is proven by the sig F value of 0,000 less than $\alpha(0.05)$. There is a positive and significant effect of Competence on the Performance of Certified Teachers in Palembang 7 Public Middle School with a sig t value of $0,000<\alpha(0.05)$. There is a positive and significant effect of Compensation on the Performance of Certified Teachers in SMP Negeri 7 Palembang with a sig t value of $0.007<\alpha(0.05)$. There is a positive and significant influence of Motivation on the Performance of certified Teachers in Palembang 7 Public Middle School with a sig t value of 0.049 $<\alpha(0.05)$. Correlation $(\mathrm{R})$ influence variables Competency $\left(\mathrm{X}_{1}\right)$, Compensation $\left(\mathrm{X}_{2}\right)$ and Motivation $\left(\mathrm{X}_{3}\right)$ together to the Performance of Certified Teachers (Y) is 0.625 meaning the relationship of Competence, Compensation and Motivation together with the Performance of Certified Teachers Palembang 7 Public Middle School showed a strong and positive correlation. The coefficient of determination (R-square) is 0.391 which gives an understanding that $39.1 \%$ of the Performance of Certified Civil Servant Teachers (Y) can be explained or influenced by Competency $\left(\mathrm{X}_{1}\right)$, Compensation $\left(X_{2}\right)$ and Motivation $\left(X_{3}\right)$ together while the remaining $60,9 \%$ is influenced by other factors not examined
\end{abstract}

Keywords: Performance, Competence, Compensation and Motivation

\section{PENDAHULUAN}

Pendidikan adalah salah satu institusi yang berperan menyiapkan sumber daya manusia. Sejalan dengan perkembangan zaman, tantangan yang dihadapi sistem pendidikan semakin meningkat baik kualitas, kuantitas maupun relevansinya. Perkembangan masyarakat yang diikuti dengan perkembangan kebutuhannya memunculkan jenis-jenis dan bentuk-bentuk pekerjaan baru yang memerlukan penyesuaian spesifikasi kemampuan dan persyaratan dari tenaga kerjanya, As'ari (2008:1). Arus globalisasi menimbulkan tantangan daya saing terhadap produk barang dan jasa. Sistem pendidikan yang bermutu akan mampu meningkatkan kualitas sumber daya manusia.

\footnotetext{
*) corresponding author

Yuniarti

STIA Bala Putra Dewa

Jl. Urip Sumoharjo, 2 Ilir, Kec. Ilir Tim. II, Kota Palembang, Sumatera Selatan 30163
}

Email: ibrahimyuniarti658@gmail.com
Dalam rangka mencapai visi, misi dan tujuan pendidikan yang telah ditetapkan bersama oleh sekolah, diperlukan kondisi sekolah yang kondusif dan keharmonisan antara tenaga pendidik yang ada di sekolah antara lain, Kepala Sekolah, Guru PNS Bersertifikasi, tenaga administrasi, yang masing-masing mempunyai peran yang cukup besar dalam mencapai tujuan pendidikan. Tenaga Guru PNS Bersertifikasi salah satu tenaga kependidikan yang mempunyai peran sebagai faktor penentu keberhasilan tujuan organisasi selain tenaga kependidikan lainnya, karena Guru PNS Bersertifikasi yang langsung bersinggungan dengan peserta didik, untuk memberikan bimbingan yang muaranya akan menghasilkan tamatan yang diharapkan. Untuk itu kinerja Guru PNS Bersertifikasi harus selalu ditingkatkan.

Guru PNS Bersertifikasi memiliki peran yang sangat besar dalam pendidikan, dipundaknya dibebani suatu tanggung jawab atas mutu pendidikan. Maka dari itu Guru PNS Bersertifikasi harus mengembangkan dirinya dengan ilmu pengetahuan dan keterampilan-keterampilan yang dibutuhkan dalam pembelajaran. Sekolah sekarang sudah dihadapkan pada persaingan dan teknologi yang tidak berskala nasional akan tetapi sudah internasional, baik sekolah negeri maupun swasta. 
SMP Negeri 7 Palembang, merupakan salah satu Sekolah Menengah Pertama Negeri yang ada di Palembang, Sumatera Selatan. Sama dengan SMP pada umumnya di Indonesia masa pendidikan sekolah di SMP Negeri 7 Palembang ditempuh dalam waktu tiga tahun pelajaran, mulai dari Kelas 7 sampai Kelas IX. Belum optimalnya kinerja Guru PNS Bersertifikasi SMP Negeri 7 Palembang dapat dilihat dari Kinerja Guru PNS Bersertifikasi belum terlaksana secara optimal, hal ini tercermin dari belum optimalnya kuantitas dan kualitas kerja sesuai target yang diharapkan, serta kecepatan dan ketepatan pelaksanaan pekerjaan, masih ada Guru PNS Bersertifikasi yang belum memiliki kompetensi yang cukup, ini dapat dilihat dari kemampuannya dalam melaksanakan tugas-tugas dan tanggungjawabnya, pemberian Kompensasi yang dilaksanakan belum berdampak pada peningkatan kinerja Guru PNS Bersertifikasi,masih rendahnya motivasi yang dimiliki para Guru PNS Bersertifikasi yang terlihat dari masih rendahnya Guru PNS Bersertifikasi yang menunjukkan prestasi kerja, masih rendahnya keinginan Guru PNS Bersertifikasi untuk meningkatkan pendidikannya ke jenjang yang lebih tinggi dan masih rendahnya kecintaan Guru PNS Bersertifikasi terhadap bidang pekerjaannya, Kepala Sekolah belum sepenuhnya mampu menjadi motivator bagi peningkatan kinerja Guru PNS Bersertifikasi. Hal ini tercermin dari peluang untuk berprestasi masih minim, karena penempatan pada jabatan tidak berdasarkan prestasi kerja dan kinerja Guru PNS Bersertifikasi belum terlaksana secara optimal, hal ini tercermin dari belum optimalnya kuantitas dan kualitas kerja sesuai target yang diharapkan, serta kecepatan dan ketepatan pelaksanaan pekerjaan.

Bertitik tolak dari uraian diatas, maka peneliti tertarik untuk melakukan penelitian tentang: "Pengaruh Kompetensi, Kompensasi, dan Motivasi terhadap Kinerja Guru PNS Bersertifikasi pada SMP Negeri 7 Palembang”

\section{TINJAUAN PUSTAKA}

\section{Pengertian Kinerja}

Menurut Streers (Magdalena, 2007:147), “...kinerja individu merupakan fungsi gabungan dari tiga faktor penting. (1) kemampuan, perang, dan minat seorang pekerja; (2) kejelasan dan penerimaan atau penjelasan penentu seorang pekerja; dan (3) tingkat motivasi pekerja. Kemampuan, perangai dan minat pekerja merupakan ciriciri individu yang sangat menentukan. Kemampuan pekerja memberikan sumbangan, pada suatu organisasi pekerja yang sangat menentukan kehendak pekerja untuk menyumbang.

Selanjutnya Hernt dan Obsen (2001:59), menyatakan bahwa prestasi kerja secara formal didefinisikan sebagai kualitas dan kuantitas pencapaian tugas-tugas, baik dilakukan oleh individu kelompok ataupun organisasi. Aspek kualitas menunjukkan pada beban kerja yang telah ditetapkan dalam uraian pekerjaan, sedangkan kualitas pekerja dapat dilihat dari rapih tidaknya hasil kerja yang telah dicapai.

Husein Umar (2009:14) mengatakan kinerja atau hasil kerja adalah hasil dari proses pekerjaan yang dilakukan dalam periode tertentu dan waktu tertentu dibandingkan dengan standar kerja dalam suatu organisasi. Manajemen maupun pegawai perlu umpan balik tentang kerja mereka hasil penelitian kerja pegawai dapat memperbaiki keputusan-keputusan personalia dan memberikan umpan balik kepada pegawai tentang pelaksanaan kerja mereka.
Jadi dapat disimpulkan bahwa kinerja adalah prestasi seseorang Guru PNS Bersertifikasi dalam suatu bidang atau keahlian tertentu, dalam melaksanakan pekerjaannya yang didelegasikan dari atasan dengan efektif dan efesien. Secara operasional kinerja teridentifikasi melalui kemampuan kerja, terpenuhinya fasilitas penunjang kerja dan prosedur kerja.

\section{Kompetensi}

Kompetensi merupakan karakteristik yang mendasari seseorang dan berkaitan dengan efektivitas kinerja individu dalam pekerjaannya (an underlying characterictic's of an individual which is causally related to ceiterion referenced effective or superior performance in a job or solution) Spencer, (2003:32).

Kompetensi pada dasarnya melekat pada setiap jabatan (kompetensi jabatan) dan setiap pegawai (profil kompetensi individu). Kompetensi jabatan adalah kompetensi yang dipersyaratkan sesuai dengan karakteristik suatu jabatan. Sedangkan profil kompetensi individu adalah karakteristik individu pada format yang telah ditentukan. Spencer, (2003:48).

Kompetensi yang dimaksud dalam penelitian ini adalah kemampuan. faktor yang mempengaruhi kemampuan pegawai adalah faktor pengetahuan dan keterampilan. Hal ini sesuai dengan pendapat Keith Davis dalam Mangkunegara (2000:67) yang merumuskan bahwa ability $=$ Knowledge + skill. Secara psikologis kemampuan pegawai terdiri dari kemampuan potensi dan kemampuan reality. Artinya pegawai yang memiliki kemampuan di atas rata-rata dengan pendidikan atau pengetahuan yang memadai untuk menjalankan pekerjaan yang terampil dalam mengerjakan pekerjaan sehari-hari, maka ia akan lebih mudah mencapai kinerja (prestasi) yang diharapkan. Oleh karena itu, pegawai perlu ditempatkan pada pekerjaan yang sesuai dengan keahliannya (the right man in the right place, the right man on the right job).

Dari pengertian diatas, maka kompetensi yang dimaksud dalam penelitian ini adalah kemampuan yang dibutuhkan Guru PNS Bersertifikasi di SMP Negeri 7 Palembang. dalam menjalankan tugasnya. Secara operasional kompetensi teridentifikasi melalui pengetahuan, keterampilan dan pengalaman.

\section{Kompensasi}

Adapun defenisi Kompensasi menurut Terry dalam Ranupandojo dan Husnan (2002:28) adalah Incentive is an important actuating tool. Human being tend to strive more itensely when the reward for accomplishing satisfies their personal demand. Artinya: Kompensasi adalah suatu alat penggerak yang penting. Manusia cenderung untuk berusaha lebih giat apabila balas jasa yang diterima memberikan kepuasan terhadap apa yang diminta.

Menurut Sukma (2001:34) menyatakan bahwa Kompensasi adalah dorongan untuk pegawai agar bekerja dengan efektif dan efisien. Sedangkan menurut Hasibuan (2000:42) menyatakan bahwa Kompensasi adalah semua pendapatan yang berbentuk uang, barang langsung atau tidak langsung yang diterima pegawai sebagai imbalan atas jasa yang diberikan kepada perusahaan.

Menurut Ranupandojo dan Husnan (2002:49) Kompensasi adalah pemberian perangsang kepada pegawai agar setiap pegawai melakukan tugasnya dengan baik. Dengan kata lain Kompensasi itu adalah hal-hal atau usaha yang harus diperhatikan dan dibangun untuk mengairahkan pegawai agar rajin bekerja dan dapat mencapai hasil yang lebih baik sehingga tercipta efektifitas 
kerja pegawai. Sedangkan menurut Nawawi (2003:22) menyatakan bahwa Kompensasi adalah imbalan bagi organisasi/perusahaan yang berarti penghargaan kepada para pekerja yang telah memberikan kontribusi dalam mewujudkan tujuannya melalui kegiatan yang disebut bekerja.

Dari penjelasan di atas dapat disimpulkan bahwa Kompensasi adalah usaha yang harus diperhatikan dan dibangun untuk mengairahkan pegawai agar rajin bekerja dan dapat mencapai hasil yang lebih baik. Secara operasional Kompensasi teridentifikasi melalui dimensi yaitu keadilan dan kelayakan.

\section{Motivasi}

Menurut Robbins (2006:214), motivasi adalah proses yang berperan pada intensitas, arah dan lamanya berlangsung upaya individu kearah pencapaian sasaran. Ada banyak teori mengenai motivasi yang dikemukan oleh banyak ahli diantaranya adalah sebagai berikut:

1) Teori Hirarki

Teori hirarki yang terkenal adalah teori yang dikemukakan oleh Maslow. Maslow mengemukakan bahwa mootivasi adalah suatu fungsi dari lima kebutuhan dasar yaitu (Kreitner, 2005:252):

1. Fisiologis

2. Keselamatan atau keamanan

3. Rasa memiliki (belongingness) atau social

4. Penghargaan

5. Aktualisasi diri

Teori kebutuhan Maslow dapat digambarkan dibawah ini :

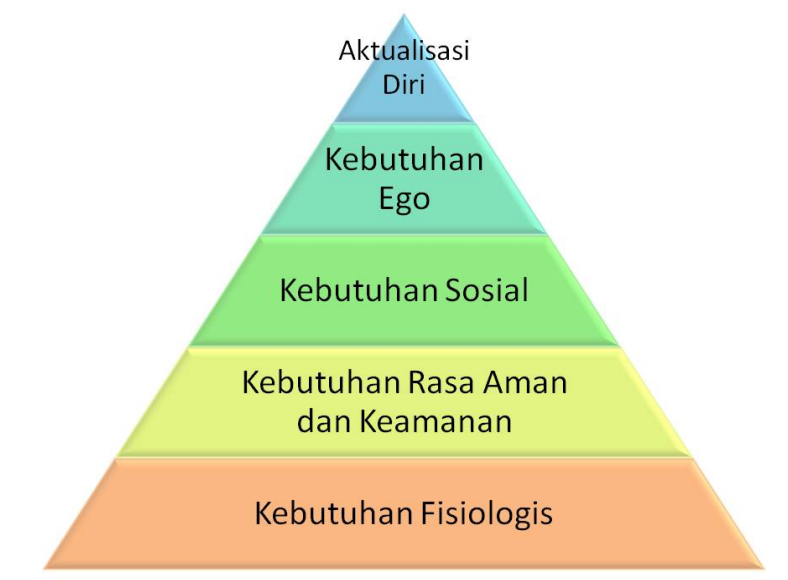

Sumber: Teori Maslow (Kreitner, 2005:253)

\section{Gambar 1. Teori Maslow dan Teori Herzberg}

Lima peringkat kebutuhan yang tersusun dalam suatu tatanan hirarkis, dimana kebutuhan fisiologis yang berada pada urutan lebih bawah, keselamatan dan keamanan berikutnya, kebutuhan akan rasa memiliki (belonging) ditengah, penghargaan (esteem) lebih tinggi dan kebutuhan tubuh dipenuhi, orang mencari kepuasan akan keselamatan dan keamanan, lalu ketika orang merasa aman, ia termotivasi oleh kebutuhan berikutnya penghargaan. Ketika pekerja mampu memuaskan semua kebutuhannya yang lebih rendah, apa yang ia anggap terpenting atau memuaskan adalah keinginan untuk melakukan sesuatu yang berharga dan tercapainya keinginan tersebut.

\section{METODE PENELITIAN}

\section{Tempat dan Waktu Penelitian}

Penelitian ini dilaksanakan Pada SMP Negeri 7 Palembang. Dipilihnya tempat penelitian ini dikarenakan penulis tertarik untuk mengetahui tentang bagaimana Kinerja yang terjadi Pada SMP Negeri 7 Palembang sehubungan dengan adanya kompetensi, kompensasi dan motivasi. Penelitian ini dilakukan dalam waktu 5 (lima) bulan dimulai sejak bulan Juni 2019 sampai dengan bulan Oktober 2019.

\section{Populasi dan Sampel}

Populasi dan wilayah generalisasi yang terdiri atas obyek/subyek yang mempunyai kuantitas dan karakteristik tertentu yang ditetapkan oleh peneliti untuk dipelajari dan kemudian ditarik kesimpulannya (Supranto, 2003:76). Populasi dalam penelitian ini adalah Guru PNS Bersertifikasi pada SMP Negeri 7 Palembang yang berjumlah 40 Guru PNS bersertifikasi.

Menurut Sugiyono (2008:118) sampel adalah sebagian dari jumlah dan karakteristik yang dimiliki oleh populasi tersebut. Dalam penelitian ini teknik pengambilan sampel yang dilakukan dengan menggunakan metode sampel jenuh atau pengambilan sampel diambil dari seluruh jumlah populasi. Beberapa hal yang dapat dipakai sebagai petunjuk untuk menentukan besarnya persentase sampel yaitu bila populasi $\mathrm{N}$ besar, persentase yang kecil saja sudah dapat memenuhi syarat dan besarnya sampel hendaknya jangan kurang dari 30.

Dalam penelitian ini sampel yang diambil adalah seluruh Guru yang berstatus PNS Bersertifikasi yang berjumlah 40 orang sebagai sampel data uji coba dan data penelitian.

\section{Teknik Analisis Data}

\section{Analisis Statistik Inferensial}

a. Model Regresi berganda

Model regresi ganda untuk mengukur pengaruh Kompetensi $\left(\mathrm{X}_{1}\right)$ Kompensasi $\left(\mathrm{X}_{2}\right)$ danMotivasi $\left(\mathrm{X}_{3}\right)$ secara bersama-sama terhadap Kinerja $(\mathrm{Y})$.

$$
\begin{aligned}
& \hat{\mathbf{Y}=} \mathbf{a}+\mathbf{b}_{1} \mathbf{X}_{\mathbf{1}}+\mathbf{b}_{\mathbf{2}} \mathbf{X}_{\mathbf{2}}+\mathbf{b}_{\mathbf{3}} \mathbf{X}_{\mathbf{3}}+\mathbf{e} \\
& \text { Dimana: } \\
& \hat{Y} \quad=\text { Variabel Kinerja } \\
& \mathrm{a} \quad=\text { Konstanta Regresi } \\
& \mathrm{b}_{1,} \mathrm{~b}_{2,} \mathrm{~b}_{3}=\text { Koefisien regresi } \\
& \mathrm{X}_{1}=\text { Variabel Kompetensi } \\
& \mathrm{X}_{2} \quad=\text { Variabel Kompensasi } \\
& \mathrm{X}_{3} \quad=\text { Variabel Motivasi } \\
& \mathrm{e} \quad=\text { Residual/Konstanta }
\end{aligned}
$$

\section{b. Koefisien Korelasi}

Untuk mengetahui keeratan hubungan antara Kompetensi, Kompensasi dan Motivasi dengan Kinerja Guru PNS Bersertifikasi pada SMP Negeri 7 Palembang digunakan besaran yang akan dianalisis adalah korelasi ( $r$ ). Korelasi adalah salah satu teknik statistik yang digunakan untuk mencari hubungan antara dua variabel atau lebih. Dalam hal ini tidak ditentukan variabel mana yang mempengaruhi variabel yang lainnya. Nilai koefisien berkisar antara -1 dan 1 . Semakin mendekati satu nilai absolut koefisien korelasi maka hubungan antara variabel tersebut semakin kuat, sedangkan semakin kecil 
(mendekati nol) nilai absolut koefisien korelasi maka hubungan antara variabel tersebut semakin lemah. Tanda positif atau negatif menunjukkan arah hubungan.

Kuat dan lemahnya korelasi antara variabel tidak ada ukuran yang pasti, menurut Young (2001: 317), ukuran korelasi diterjemahkan sebagai berikut:

1. $0,80-1,00$ (baik positif atau negatif) menunjukkan adanya derajat asosiasi yang tinggi;

2. $0,60-<0,80$ (baik positif atau negatif) menunjukkan hubungan yang substansial;

3. $0,40-0,60$ (baik positif atau negatif) menunjukkan adanya korelasi yang sedang;

4. $0,20-0,40$ (baik positif atau negatif) menunjukkan hubungan yang rendah;

5. 0,00 - 0,20 (baik positif atau negatif) menunjukkan hubungan yang sangat rendah;

\section{c. Koefisien Determinasi}

Untuk mengambil seberapa jauh variabel bebas dapat menjelaskan variabel terikat, maka perlu diketahui nilai koefisien determinasi atau penentuan $\mathrm{R}^{2}$.

Nilai $R^{2}$ ini berkisar antara $0-1$, semakin mendekati 1 nilai $\mathrm{R}^{2}$ tersebut berarti semakin besar variabel independen (X) mampu menerangkan variabel dependent (Y). Analisis terhadap nilai $\mathrm{R}$-square $\left(\mathrm{R}^{2}\right)$ ini digunakan untuk mengetahui sejauh mana variabel bebas $\left(X_{1}, X_{2}\right.$ dan $\left.X_{3}\right)$ dapat menerangkan hubungan perubahan variabel terikat (Y). sifat-sifat R-square sangat dipengaruhi oleh banyak variabel bebas dimana semakin banyak variabel bebas semakin besar nilai R-square.

\section{Hipotesis Statistika}

1. Hipotesis pertama: Terdapat Pengaruh positif dan signifikan Kompetensi, Kompensasi dan Motivasi secara bersama-sama terhadap Kinerja Guru PNS Bersertifikasi pada SMP Negeri 7 Palembang.

\begin{abstract}
$\mathrm{H}_{0}: \mathrm{b}_{1}, \mathrm{~b}_{2}, \mathrm{~b}_{3}=0 \quad$ Tidak terdapat Pengaruh positif dan signifikan Kompetensi, Kompensasi dan Motivasi secara bersama-sama terhadap Kinerja Guru PNS Bersertifikasi pada SMP Negeri 7 Palembang.

$\mathrm{H}_{0}: \mathrm{b}_{1}, \mathrm{~b}_{2}, \mathrm{~b}_{3} \neq 0$ terdapat Pengaruh positif dan signifikan Kompetensi, Kompensasi dan Motivasi secara bersamasama terhadap Kinerja Guru PNS Bersertifikasi pada SMP Negeri 7 Palembang.
\end{abstract}
a. Formula Pengujian
b. Level of Significance 95\% $(\alpha=0,05)$
c. Kriteria Pengujian:

- $\quad$ Terima $\mathrm{H}_{0}$, jika sig. $\mathrm{F} \geq 0,05$

- $\quad$ Tolak $\mathrm{H}_{0}$, jika sig. $\mathrm{F}<0,05$
$\mathrm{H}_{0}: \mathrm{b}_{1}=0$
Tidak Terdapat Pengaruh positif dan signifikan Kompetensi terhadap KinerjaGuru PNS Bersertifikasi pada SMP Negeri 7 Palembang
$\mathrm{H}_{0}: \mathrm{b}_{1} \neq 0$
Terdapat Pengaruh positif dan signifikan Kompetensi terhadap Kinerja Guru PNS Bersertifikasi pada SMP Negeri 7 Palembang.
2. Hipotesis Kedua: Terdapat Pengaruh positif dan signifikan Kompetensi terhadap Kinerja Guru PNS Bersertifikasi pada SMP Negeri 7 Palembang.
a. Formula Pengujian
b. Level of Significance 95\% $(\alpha=0,05)$
c. Kriteria Pengujian:

- Terima $\mathrm{H}_{0}$, jika sig. $\mathrm{t} \geq 0,05$

- Tolak $\mathrm{H}_{0}$, jika sig. $\mathrm{t}<0,05$

3. Hipotesis Ketiga: Terdapat Pengaruh positif dan signifikan Kompensasi terhadap Kinerja Guru PNS Bersertifikasi pada SMP Negeri 7 Palembang.

\footnotetext{
$\mathrm{H}_{0}: \mathrm{b}_{2}=0$, Tidak Terdapat Pengaruh positif dan signifikan Kompensasi terhadap Kinerja Guru PNS Bersertifikasi pada SMP Negeri 7 Palembang.

$\mathrm{H}_{0}: \mathrm{b}_{2} \neq 0, \quad$ Terdapat Pengaruh positif dan signifikan Kompensasi terhadap Kinerja Guru PNS Bersertifikasi pada SMP Negeri 7 Palembang.
}

a. Formula Pengujian

b. Level of Significance $95 \%(\alpha=0,05)$

c. Kriteria Pengujian:

- Terima $\mathrm{H}_{0}$, jika sig. $\mathrm{t} \geq 0,05$

- Tolak $\mathrm{H}_{0}$, jika sig. $\mathrm{t}<0,05$
4. Hipotesis Keempat: Terdapat pengaruh positif dan signifikan motivasi terhadap Kinerja Guru PNS Bersertifikasi pada SMP Negeri 7 Palembang.

\footnotetext{
$\mathrm{H}_{0}: \mathrm{b}_{3}=0, \quad$ Terdapat pengaruh positif dan signifikan motivasi terhadap Kinerja Guru PNS Bersertifikasi pada SMP Negeri 7 Palembang.

$\mathrm{H}_{0}: \mathrm{b}_{3} \neq 0$, Terdapat pengaruh positif dan signifikan motivasi terhadap Kinerja Guru PNS Bersertifikasi pada SMP Negeri 7 Palembang.
}

\author{
a. Formula Pengujian \\ b. Level of Significance 95\% $(\alpha=0,05)$ \\ c. Kriteria Pengujian: \\ - Terima $\mathrm{H}_{0}$, jika sig. $\mathrm{t} \geq 0,05$ \\ - $\quad$ Tolak $\mathrm{H}_{0}$, jika sig. $\mathrm{t}<0,05$
}

\section{HASIL PENELITIAN}

\section{Analisis Regresi Linear Berganda}

Untuk menetapkan persamaan regresi linear ganda pengaruh Kompetensi $\left(\mathrm{X}_{1}\right)$, Kompensasi $\left(\mathrm{X}_{2}\right)$ dan Motivasi $\left(\mathrm{X}_{3}\right)$ secara bersama - sama terhadap Kinerja Guru PNS bersertifikasi $(Y)$ perlu dilakukan analisis koefisien regresi berganda. Dengan menggunakan fasilitas program SPSS, hasil analisis ditampilkan pada tabel 4.20 berikut ini: 
Tabel 4.2

Pengaruh Kompetensi, Kompensasi dan Motivasi terhadap Kinerja Guru PNS bersertifikasi

Coefficients $^{\mathrm{a}}$

\begin{tabular}{|c|c|c|c|c|c|c|}
\hline \multirow[b]{2}{*}{ Mode } & & \multicolumn{2}{|c|}{$\begin{array}{c}\text { Unstandardized } \\
\text { Coefficients }\end{array}$} & \multirow{2}{*}{$\begin{array}{c}\text { Standardized } \\
\text { Coefficients }\end{array}$} & \multirow[b]{2}{*}{$t$} & \multirow[b]{2}{*}{ Sig. } \\
\hline & & B & Std. Error & & & \\
\hline 1 & (Constant) & 6.306 & 17.983 & & .351 & .728 \\
\hline & Kompetensi & .551 & .135 & .557 & 4.078 & .000 \\
\hline & Kompensasi & .389 & .137 & .388 & 2.834 & .007 \\
\hline & Motivasi & .236 & .116 & .266 & 2.038 & .049 \\
\hline
\end{tabular}

a. Dependent Variable: Kinerja

Berdasarkan hasil analisis koefisien regresi ganda pada tabel 4.2 tersebut, maka persamaan regresi linear ganda pengaruh Kompetensi $\left(\mathrm{X}_{1}\right)$, Kompensasi $\left(\mathrm{X}_{2}\right)$ dan Motivasi $\left(\mathrm{X}_{3}\right)$ terhadap Kinerja Guru PNS bersertifikasi (Y) adalah:

$$
\hat{\mathrm{Y}}=6,306+0,551 \mathrm{X} 1+0,389 \mathrm{X} 2+0,236 \mathrm{X} 3+\mathrm{e}
$$

Dari persamaan di atas dapat dijelaskan bahwa konstanta regresi adalah 6,306, artinya jika mengabaikan variabel Kompetensi, Kompensasi dan Motivasi maka skor Kinerja Guru PNS bersertifikasi sebesar 6,306. Koefisien regresi Kompetensi $\left(\mathrm{X}_{1}\right)$ adalah 0,551 , artinya setiap penambahan satu satuan skor Kompetensi, akan meningkatkan skor Kinerja Guru PNS bersertifikasi sebesar 0,551 satuan skor dengan menjaga skor Kompensasi $\left(\mathrm{X}_{2}\right)$ dan Motivasi $\left(X_{3}\right)$ tetap/konstan. Koefisien regresi Kompensasi $\left(\mathrm{X}_{2}\right)$ adalah 0,389 , artinya setiap penambahan satu satuan skor variabel Kompensasi $\left(\mathrm{X}_{2}\right)$ akan meningkatkan skor Kinerja Guru PNS bersertifikasisebesar 0,389 satuan skor dengan menjaga skor Kompetensi $\left(X_{1}\right)$ dan Motivasi $\left(\mathrm{X}_{3}\right)$ tetap/konstan. Koefisien regresi Motivasi $\left(X_{3}\right)$ adalah 0,236 , artinya setiap penambahan satu satuan skor variabel Motivasi $\left(\mathrm{X}_{3}\right)$ akan meningkatkan skor Kinerja Guru PNS bersertifikasisebesar 0,236 dengan menjaga skor Kompetensi $\left(\mathrm{X}_{1}\right)$ dan Kompensasi $\left(\mathrm{X}_{2}\right)$ tetap/konstan.

\section{Analisis Regresi Linear Sederhana}

\section{Pengaruh Kompetensi (X1), terhadap Kinerja Guru PNS bersertifikasi ( $\mathrm{Y}$ )}

Untuk menetapkan persamaan regresi linear sederhana pengaruh Kompetensi $\left(\mathrm{X}_{1}\right)$, terhadap Kinerja Guru PNS bersertifikasi $(\mathrm{Y})$ perlu dilakukan analisis koefisien regresi sederhana. Dengan menggunakan fasilitas program SPSS, hasil analisis ditampilkan pada tabel 4.21 berikut ini:

\section{Tabel 4.21}

Pengaruh Kompetensi, terhadap Kinerja Guru PNS bersertifikasi

Coefficients $^{\mathrm{a}}$

\begin{tabular}{|c|c|c|c|c|c|c|}
\hline \multirow[b]{2}{*}{ Model } & & \multicolumn{2}{|c|}{$\begin{array}{c}\text { Unstandardized } \\
\text { Coefficients }\end{array}$} & \multirow{2}{*}{$\begin{array}{c}\text { Standardized } \\
\text { Coefficients } \\
\text { Beta }\end{array}$} & \multirow[b]{2}{*}{ t } & \multirow[b]{2}{*}{ Sig. } \\
\hline & & $B$ & Std. Error & & & \\
\hline \multirow[t]{2}{*}{1} & (Constant) & 44.725 & 10.838 & & 4.127 & .000 \\
\hline & Kompetensi & .442 & .144 & .446 & 3.071 & .004 \\
\hline
\end{tabular}

a. Dependent Variable: Kinerja

Berdasarkan hasil analisis koefisien regresi sederhana pada tabel 29 tersebut, maka persamaan regresi linear sederhana pengaruh Kompetensi $\left(\mathrm{X}_{1}\right)$ terhadap Kinerja Guru PNS bersertifikasi (Y) adalah:

$$
\hat{\mathrm{Y}}=44,725+0,442 \mathrm{X} 1+\mathrm{e}
$$

Dari persamaan di atas dapat dijelaskan bahwa konstanta regresi adalah 44,725, artinya jika mengabaikan variabel Kompetensi, maka skor Kinerja Guru PNS bersertifikasi sebesar 44,725. Koefisien regresi Kompetensi $\left(\mathrm{X}_{1}\right)$ adalah 0,442 , artinya setiap penambahan satu satuan skor Kompetensi, akan meningkatkan skor Kinerja Guru PNS bersertifikasi sebesar 0,442 satuan skor dengan menjaga skor Kompensasi $\left(\mathrm{X}_{2}\right)$ dan Motivasi $\left(\mathrm{X}_{3}\right)$ tetap/konstan.

\section{Pengaruh Kompensasi $\left(\mathrm{X}_{2}\right)$, terhadap Kinerja Guru PNS bersertifikasi ( $\mathrm{Y}$ )}

Untuk menetapkan persamaan regresi linear sederhana pengaruh Kompensasi $\left(\mathrm{X}_{2}\right)$, terhadap Kinerja Guru PNS bersertifikasi $(\mathrm{Y})$ perlu dilakukan analisis koefisien regresi sederhana. Dengan menggunakan fasilitas program SPSS, hasil analisis ditampilkan pada tabel 4.22 berikut ini:

\section{Tabel 4.22}

Pengaruh Kompensasi, terhadap Kinerja Guru PNS bersertifikasi

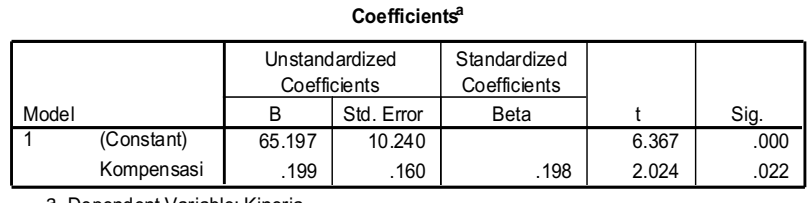

. Dependent Variable: Kinerja

Berdasarkan hasil analisis koefisien regresi sederhana pada tabel 30 tersebut, maka persamaan regresi linear sederhana pengaruh Kompetensi $\left(\mathrm{X}_{1}\right)$ terhadap Kinerja Guru PNS bersertifikasi (Y) adalah:

$$
\hat{\mathrm{Y}}=65,197+0,199 \mathrm{X} 2+\mathrm{e}
$$

Dari persamaan di atas dapat dijelaskan bahwa konstanta regresi adalah 65,197, artinya jika mengabaikan variabel Kompensasi, maka skor Kinerja Guru PNS bersertifikasi sebesar 65,197. Koefisien regresi Kompensasi $\left(\mathrm{X}_{2}\right)$ adalah 0,199, artinya setiap penambahan satu satuan skor Kompensasi, akan meningkatkan skor Kinerja Guru PNS bersertifikasi sebesar 0,199 satuan skor dengan menjaga skor Kompetensi $\left(\mathrm{X}_{1}\right)$ dan Motivasi $\left(\mathrm{X}_{3}\right)$ tetap/konstan.

\section{Pengaruh Motivasi $\left(\mathrm{X}_{3}\right)$, terhadap Kinerja Guru PNS bersertifikasi $(\mathrm{Y})$}

Untuk menetapkan persamaan regresi linear sederhana pengaruh Motivasi $\left(\mathrm{X}_{3}\right)$, terhadap Kinerja Guru PNS bersertifikasi $(\mathrm{Y})$ perlu dilakukan analisis koefisien regresi sederhana. Dengan menggunakan fasilitas program SPSS, hasil analisis ditampilkan pada tabel 4.23 berikut ini:

Tabel 4.23

\begin{tabular}{|c|c|c|c|c|c|c|}
\hline \multirow[b]{2}{*}{ Model } & & \multicolumn{2}{|c|}{$\begin{array}{c}\text { Unstandardized } \\
\text { Coefficients }\end{array}$} & \multirow{2}{*}{$\begin{array}{c}\text { Standardized } \\
\text { Coefficients } \\
\text { Beta }\end{array}$} & \multirow[b]{2}{*}{$t$} & \multirow[b]{2}{*}{ Sig. } \\
\hline & & $B$ & Std. Error & & & \\
\hline 1 & (Constant) & 60.984 & 10.691 & & 5.704 & .000 \\
\hline & Motivasi & .221 & .139 & .249 & 2.059 & .012 \\
\hline
\end{tabular}

Pengaruh motivasi terhadap Kinerja Guru PNS bersertifikasi

Coefficients $^{\mathrm{a}}$

a. Dependent Variable: Kinerja 
Berdasarkan hasil analisis koefisien regresi sederhana pada tabel 31 tersebut, maka persamaan regresi linear sederhana pengaruh Motivasi $\left(\mathrm{X}_{3}\right)$ terhadap Kinerja Guru PNS bersertifikasi $(\mathrm{Y})$ adalah:

$$
\hat{\mathrm{Y}}=60,984+0,221 \mathrm{X} 3+\mathrm{e}
$$

Dari persamaan di atas dapat dijelaskan bahwa konstanta regresi adalah 60,984, artinya jika mengabaikan variabel Kompensasi, maka skor Kinerja Guru PNS bersertifikasi sebesar 60,984. Koefisien regresi Kompensasi $\left(\mathrm{X}_{2}\right)$ adalah 0,221 , artinya setiap penambahan satu satuan skor Kompensasi, akan meningkatkan skor Kinerja Guru PNS bersertifikasi sebesar 0,221 satuan skor dengan menjaga skor Kompetensi $\left(\mathrm{X}_{1}\right)$ dan Kompensasi $\left(\mathrm{X}_{2}\right)$ tetap/konstan.

\section{Analisis Korelasi}

Untuk melihat kuat atau lemahnya pengaruh variabel Kompetensi, Kompensasi dan Motivasi secara simultan terhadap Kinerja Guru PNS bersertifikasi (Y) perlu dilakukan analisis korelasi, hasil analisis korelasi ditampilkan pada tabel 4.24 berikut ini:

Tabel 4.24

Koefisien Korelasi dan Determinasi Pengaruh Kompetensi, Kompensasi dan Motivasi terhadap Kinerja Guru PNS bersertifikasi

\section{Model Summary}

\begin{tabular}{|l|r|r|r|r|}
\hline Model & $\mathrm{R}$ & R Square & $\begin{array}{c}\text { Adjusted } \\
\text { R Square }\end{array}$ & $\begin{array}{c}\text { Std. Error of } \\
\text { the Estimate }\end{array}$ \\
\hline 1 & $.625^{\mathrm{a}}$ & .391 & .340 & 5.987 \\
\hline
\end{tabular}

a. Predictors: (Constant), Motivasi, Kompetensi, Kompensasi

Berdasarkan Tabel 4.24 di atas menunjukkan koefisien Korelasi ( $R$ ) variabel pengaruh Kompetensi ( $\left.\mathrm{X}_{1}\right)$, Kompensasi $\left(\mathrm{X}_{2}\right)$ dan Motivasi $\left(\mathrm{X}_{3}\right)$ secara bersama-sama terhadap Kinerja Guru PNS bersertifikasi (Y) adalah 0,625 artinya hubungan Kompetensi, Kompensasi dan Motivasi secara bersama-sama dengan Kinerja Guru PNS bersertifikasi SMP Negeri 7 Palembang menunjukkan adanya korelasi yang kuat dan bersifat positif.

\section{Analisis Determinasi}

Untuk mengetahui berapa besar pengaruh tersebut dapat dilihat dari nilai koefisien determinasinya $\left(R_{\text {square }}\right)$ yaitu 0,391 yang memberikan pengertian bahwa 39,1\% Kinerja Guru PNS bersertifikasi $(\mathrm{Y})$ dapat dijelaskan atau dipengaruhi oleh Kompetensi $\left(\mathrm{X}_{1}\right)$, Kompensasi $\left(\mathrm{X}_{2}\right)$ dan Motivasi $\left(\mathrm{X}_{3}\right)$ secara bersama-sama sedangkan sisanya sebesar 60,9\% dipengaruhi oleh faktor lain yang tdak diteliti.

\section{Uji Hipotesis Statistik}

1. Hipotesis Pertama: Terdapat pengaruh yang signifikan Kompetensi, Kompensasi dan Motivasi secara bersamasama terhadap Kinerja Guru PNS bersertifikasi SMP Negeri 7 Palembang.

a). Formula Pengujian :

$\mathrm{H}_{0} \quad \mathrm{~b}_{1}=\mathrm{b}_{2}=\mathrm{b}_{3}=0$, tidak terdapat pengaruh yang signifikan Kompetensi, Kompensasi dan Motivasi secara bersama-sama terhadap Kinerja Guru PNS bersertifikasi SMP Negeri 7 Palembang .

$\mathrm{H}_{1}: \mathrm{b}_{1} ; \mathrm{b}_{2} ; \mathrm{b}_{3} \neq 0$,Terdapat pengaruh yang signifikan Kompetensi, Kompensasi dan Motivasi secara bersamasama terhadap Kinerja Guru PNS bersertifikasi SMP Negeri 7 Palembang .
b). Level of Significance 95\% ( $\alpha=0,05$ )
c). Kriteria Pengujian :
Ho diterima, apabila sig. $\mathrm{F} \geq 0.05$
Ho ditolak, apabila sig. $\mathrm{F}<0.05$

\section{Tabel 4.25}

Uji F

\begin{tabular}{|c|c|c|c|c|c|c|}
\hline \multicolumn{7}{|c|}{$A N O V A^{b}$} \\
\hline Model & & $\begin{array}{l}\text { Sum of } \\
\text { Squares }\end{array}$ & $d f$ & Mean Square & $\mathrm{F}$ & Sig. \\
\hline 1 & Regression & 828.910 & 3 & 276.303 & 7.710 & $.000^{2}$ \\
\hline & Residual & 1290.190 & 36 & 35.839 & & \\
\hline & Total & 2119.100 & 39 & & & \\
\hline
\end{tabular}

a. Predictors: (Constant), Motivasi, Kompetensi, Kompensasi

b. Dependent Variable: Kinerja

Berdasarkan tabel 4.25 di atas hasil sig uji. $\mathbf{F}$ sebesar $0,000<0,05$, artinya pada tingkat keyakinan $95 \% \mathrm{H}_{0}$ ditolak atau secara bersama variabel Kompetensi $\left(\mathrm{X}_{1}\right)$, Kompensasi $\left(\mathrm{X}_{2}\right)$ dan Motivasi $\left(\mathrm{X}_{3}\right)$ bisa menjelaskan skor Kinerja Guru PNS bersertifikasi (Y). Dengan demikian, dapat dikatakan bahwa hipotesis Pertama diterima. Dengan kata lain, makin tinggi Kompetensi, Kompensasi yang efektif dan makin tinggi Motivasi bagi para Guru PNS bersertifikasi SMP Negeri 7 Palembang, maka makin tinggi pula Kinerja yang diperlihatkan oleh para Guru PNS bersertifikasi tersebut. Sebaliknya, makin rendah Kompetensi, Kompensasi yang efektif dan makin rendah program Motivasi bagi Guru PNS bersertifikasi, maka makin rendah pula Kinerja yang diperlihatkan oleh para Guru PNS bersertifikasi tersebut.

2. Hipotesis Kedua: Terdapat pengaruh yang signifikan Kompetensi terhadap Kinerja Guru PNS bersertifikasi SMP Negeri 7 Palembang .

a). Formula Pengujian :

$\mathrm{H}_{0}: \mathrm{b}_{1}=0$, Tidak terdapat pengaruh yang signifikan Kompetensi terhadap Kinerja Guru PNS bersertifikasi SMP Negeri 7 Palembang .

$\mathrm{H}_{1}: \mathrm{b}_{1} \neq 0$, Terdapat pengaruh yang signifikan Kompetensi terhadap Kinerja Guru PNS bersertifikasi SMP Negeri 7 Palembang

b). Level of Significance 95\% ( $\alpha=0,05$ )

c). Kriteria Pengujian :

Ho diterima, apabila sig. $\mathrm{t} \geq 0.05$

Ho ditolak, apabila sig. $\mathrm{t}<0.05$

Berdasarkan tabel $4.20 \mathrm{di}$ atas hasil uji.t nilai signifikansi sebesar $0,000<0,05$, artinya pada tingkat keyakinan $95 \% \mathrm{H}_{0}$ ditolak atau secara individu variabel Kompetensi $\left(\mathrm{X}_{1}\right)$ bisa menjelaskan skor Kinerja Guru PNS bersertifikasi (Y). Dengan demikian, dapat dikatakan bahwa hipotesis kedua diterima. Dengan kata lain, makin tinggi dan periodik Kompetensi yang diterapkan pada Guru PNS bersertifikasi SMP Negeri 7 Palembang, maka makin 
tinggi pula Kinerja yang diperlihatkan oleh para Guru PNS bersertifikasi. Sebaliknya, makin rendah Kompetensi, maka makin rendah pula Kinerja yang diperlihatkan Guru PNS bersertifikasi SMP Negeri 7 Palembang.

3. Hipotesis Ketiga: Terdapat pengaruh yang signifikan Kompensasi terhadap Kinerja Guru PNS bersertifikasi SMP Negeri 7 Palembang .

a). Formula Pengujian :

$\mathrm{H}_{0}: \mathrm{b}_{2}=0$,

$\mathrm{H}_{1}: \mathrm{b}_{2} \neq 0$,

b). Level of Significance 95\% ( $\alpha=0,05$ )

\section{c). Kriteria Pengujian :}

Ho diterima, apabila sig. $\mathrm{t} \geq 0.05$

Ho ditolak, apabila sig. $\mathrm{t}<0.05$

Berdasarkan tabel 4.20 di atas hasil uji.t nilai signifikansi sebesar $0,007<0,05$, artinya pada tingkat keyakinan $95 \% \mathrm{H}_{0}$ ditolak atau secara individu variabel Kompensasi $\left(\mathrm{X}_{2}\right)$ bisa menjelaskan skor Kinerja Guru PNS bersertifikasi (Y). Dengan demikian, dapat dikatakan bahwa hipotesis ketiga diterima. Dengan kata lain, Kompensasi yang diterapkan para Guru PNS bersertifikasi SMP Negeri 7 Palembang efektif, maka makin tinggi pula Kinerja yang diperlihatkan oleh para Guru PNS bersertifikasi tersebut. Sebaliknya, makin rendah Kompensasi bagi para Guru PNS bersertifikasi, maka makin rendah pula Kinerja yang diperlihatkan oleh Guru PNS bersertifikasi tersebut.

4. Hipotesis Keempat: Terdapat pengaruh yang signifikan Motivasi terhadap Kinerja Guru PNS bersertifikasi SMP Negeri 7 Palembang.

a). Formula Pengujian :

$\mathrm{H}_{0}: \mathrm{b}_{3}=0$

$\mathrm{H}_{1}: \mathrm{b}_{3} \neq 0$

b). Level of Significance 95\% ( $\alpha=0,05$ )

\section{c). Kriteria Pengujian :}

Ho diterima, apabila sig. $\mathrm{t} \geq 0.05$

Ho ditolak, apabila sig. $\mathrm{t}<0.05$

Berdasarkan tabel 4.20 di atas hasil uji.t nilai signifikansi sebesar $0,049<0,05$, artinya pada tingkat keyakinan $95 \% \mathrm{H}_{0}$ ditolak atau secara individu variabel Motivasi $\left(\mathrm{X}_{3}\right)$ bisa menjelaskan skor Kinerja Guru PNS bersertifikasi $(\mathrm{Y})$. Dengan demikian, dapat dikatakan bahwa hipotesis keempat diterima. Dengan kata lain, makin tinggi Motivasi bagi para Guru PNS bersertifikasi SMP Negeri 7 Palembang, maka makin tinggi pula Kinerja yang diperlihatkan oleh para Guru PNS bersertifikasitersebut. Sebaliknya, makin rendah Motivasi bagi para Guru PNS bersertifikasi, maka makin rendah pula Kinerja yang diperlihatkan oleh Guru PNS bersertifikasi tersebut.

Hasil analisa statistik yang dilakukan dengan bantuan komputer meliputi analisis regresi, korelasi dan determinasi menunjukkan hal-hal sebagai berikut :

1. Konstanta regresi adalah 6,306, artinya jika mengabaikan variabel Kompetensi, Kompensasi dan Motivasi maka skor Kinerja Guru PNS bersertifikasi sebesar 6,306. Koefisien regresi Kompetensi $\left(X_{1}\right)$ adalah 0,551 , artinya setiap penambahan satu satuan skor Kompetensi, akan meningkatkan skor Kinerja Guru PNS bersertifikasi sebesar 0,551 satuan skor dengan menjaga skor Kompensasi $\left(\mathrm{X}_{2}\right)$ dan Motivasi $\left(\mathrm{X}_{3}\right)$ tetap/konstan. Koefisien regresi Kompensasi $\left(\mathrm{X}_{2}\right)$ adalah 0,389 , artinya setiap penambahan satu satuan skor variabel Kompensasi $\left(\mathrm{X}_{2}\right)$ akan meningkatkan skor Kinerja Guru PNS bersertifikasisebesar 0,389 satuan skor dengan menjaga skor Kompetensi $\left(\mathrm{X}_{1}\right)$ dan Motivasi $\left(\mathrm{X}_{3}\right)$ tetap/konstan. Koefisien regresi Motivasi $\left(\mathrm{X}_{3}\right)$ adalah 0,236 , artinya setiap penambahan satu satuan skor variabel Motivasi $\left(\mathrm{X}_{3}\right)$ akan meningkatkan skor Kinerja Guru PNS bersertifikasisebesar 0,236 dengan menjaga skor Kompetensi $\left(\mathrm{X}_{1}\right)$ dan Kompensasi $\left(\mathrm{X}_{2}\right)$ tetap/konstan.

2. Korelasi $(\mathrm{R})$ variabel pengaruh Kompetensi $\left(\mathrm{X}_{1}\right)$,

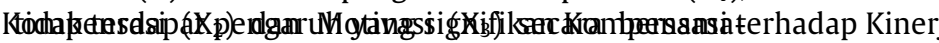

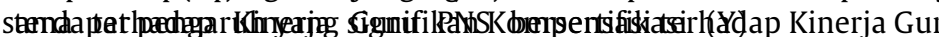
adalah 0,625 artinya hubungan Kompetensi, Kompensasi dan Motivasi secara bersama-sama dengan Kinerja Guru PNS bersertifikasi SMP Negeri 7 Palembang menunjukkan adanya korelasi yang kuat dan bersifat positif.

3. Koefisien determinasinya $\left(\mathrm{R}_{\text {square }}\right)$ yaitu 0,391 yang memberikan pengertian bahwa 39,1\% Kinerja Guru PNS bersertifikasi ( $\mathrm{Y})$ dapat dijelaskan atau dipengaruhi oleh Kompetensi $\left(\mathrm{X}_{1}\right)$, Kompensasi $\left(\mathrm{X}_{2}\right)$ dan Motivasi $\left(\mathrm{X}_{3}\right)$ secara bersama-sama sedangkan sisanya sebesar 60,9\% dipengaruhi oleh faktor lain yang tdak diteliti.

4. Berdasarkan nilai sig $\mathrm{F}$ hitung sebesar $0,000<0,05$, artinya pada tingkat keyakinan $95 \% \mathrm{H}_{0}$ ditolak atau secara bersama Kompetensi $\left(\mathrm{X}_{1}\right)$, Kompensasi $\left(\mathrm{X}_{2}\right)$ dan Motivasi $\left(\mathrm{X}_{3}\right)$ bisa menjelaskan skor Kinerja Guru PNS bersertifikasi (Y). Dengan demikian, dapat dikatakan bahwa hipotesis Pertama diterima.

5. Berdasarkan nilai sig $t$ hitung sebesar $0,000<0,05$, artinya pada tingkat keyakinan $95 \% \mathrm{H}_{0}$ ditolak atau secara individu Kompetensi $\left(\mathrm{X}_{1}\right)$ bisa menjelaskan skor Kinerja Guru PNS bersertifikasi (Y). Dengan demikian,

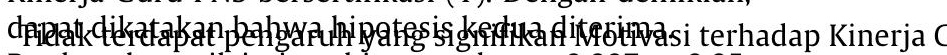

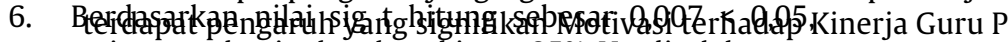
artinya pada tingkat keyakinan $95 \% \mathrm{H}_{0}$ ditolak atau secara individu variabel Kompensasi $\left(\mathrm{X}_{2}\right)$ bisa menjelaskan skor Kinerja Guru PNS bersertifikasi (Y). Dengan demikian, dapat dikatakan bahwa hipotesis ketiga diterima.

Berdasarkan nilai sig $\mathrm{t}$ hitung sebesar $0,049<0,05$, artinya pada tingkat keyakinan $95 \% \mathrm{H}_{0}$ ditolak atau secara individu variabel Motivasi $\left(\mathrm{X}_{3}\right)$ bisa menjelaskan skor Kinerja Guru PNS bersertifikasi (Y). Dengan demikian, dapat dikatakan bahwa hipotesis keempat diterima.

\section{PEMBAHASAN}

Dalam rangka mencapai visi, misi dan tujuan pendidikan yang telah ditetapkan bersama oleh sekolah, diperlukan kondisi sekolah yang kondusif dan keharmonisan antara tenaga pendidik yang ada disekolah antara lain, Kepala sekolah, guru, tenaga administrasi, yang masing-masing mempunyai peran yang cukup besar dalam mencapai tujuan pendidikan. Tenaga guru salah satu tenaga kependidikan yang mempunyai peran sebagai faktor penentu keberhasilan tujuan organisasi selain tenaga kependidikan lainnya, karena guru yang langsung bersinggungan dengan peserta didik, untuk memberikan bimbingan yang muaranya akan menghasilkan tamatan yang diharapkan. Untuk itu kinerja guru harus selalu ditingkatkan

Kinerja merupakan hal yang penting dalam memonitoring kemajuan sekolah dan merupakan fungsi operatif penting dalam sebuah sekolah, karena tanpa kinerja yang tinggi dari seluruh guru maka akan sulit bagi sekolah untuk mencapai hasil yang optimal. 
Menurut Porten dan Steers (Steer, 1997:148), ditemukan bahwa individu yang memperlihatkan perangai pribadi tertentu dalam kadar yang sangat tinggi atau rendah jauh lebih sering meninggalkan organisasi dari pada pekerja dengan tingkat perangai yang moderat. Dengan demikian kinerja individu sangat dipengaruhi oleh bermacam-macam ciri pribadi yang unik masing-masing pribadi. Tetapi perangai atau karakter seseorang tidak boleh dijadikan sebagai ukuran kinerja. Karena kalau perangai dijadikan sebagai ukuran besar kemungkinan akan terjadi penilaian yang sangat subjektif.

Dalam penelitian terdahulu yang di lakukan Angini (2014) dengan judul Pengaruh Disiplin Kerja, Kompetensi dan Motivasi Terhadap Kinerja Guru di SMA Negeri 14 Palembang menyimpulkan bahwa Terdapat pengaruh yang signifikan secara bersama-sama antara disiplin kerja, kompetensi, motivasi terhadap kinerja guru di SMA Negeri 14 Palembang. Dimana variabel Disiplin Kerja, Kompetensi guru dan Motivasi secara bersama-sama mempengaruhi peningkatan Kinerja Guru sebesar 57,4 \%sedangkan sisanya dipengaruhi oleh variabel lain yang tidak diteliti sebesar $42,6 \%$.

Upaya-upaya untuk meningkatkan kinerja itu biasanya dilakukan dengan cara meningkatkan kompetensi., memberikan motivasi danmemberikan Kompensasi Sementara kinerja guru dapat ditingkatkan apabila Kompensasi diberikan tepat waktunya, dan pihak manajemen sekolah bisa mengetahui apa yang diharapkan dan kapan bisa harapan-harapan diakui terhadap hasil kerjanya

Menurut Rivai (2005:14) menyatakan strategis sumber daya manusia juga menyangkut masalah kompetensi sumber daya manusia dalam kemampuan teknis, konsektual, dan hubungan manusiawi. Pengelolaan kompetensi tenaga kerja meliputi beberapa kompetensi sumber daya manusia seperti: kompetensi berbasis input, komptensi transpormasional, kompetensi output.

Pemberian Kompensasi merupakan salah satu hal pokok yang harus diperhatikan oleh sekolah. Bergairah tidaknya guru bisa juga disebabkan oleh besar kecilnya Kompensasi yang diterima. Apabila guru tidak mendapatkan Kompensasi yang sesuai dengan besarnya pengorbanan dalam bekerja, maka guru tersebut cenderung malas bekerja dan tidak bergairah yang pada akhirnya mereka bekerja semaunya tanpa ada motivasi yang tinggi

Guru memiliki peran yang sangat besar dalam pendidikan, dipundaknya dibebani suatu tanggung jawab atas mutu pendidikan. Maka dari itu guru harus mengembangkan dirinya dengan ilmu pengetahuan dan keterampilan-keterampilan yang dibutuhkan dalam pembelajaran. Sekolah sekarang sudah dihadapkan pada persaingan dan teknologi yang tidak berskala nasional akan tetapi sudah internasional, baik sekolah negeri maupun swasta

Motivasi dipandang sebagai elemen sentral ketika melalui sebuah proses pembelajaran pada manusia. Jika sebuah organisasi tidak dapat memotivasi peningkatan kemampuan pegawai, pengetahuan dalam sebuah organisasi tidak akan dapat dipraktekkan dan dipergunakan secara maksimum. Motivasi mengikuti pendidikan dan pelatihan menjadi tujuan dari semua kesuksesan organisasi yang sedang belajar untuk menemukan faktor yang mampu memotivasi guru untuk secara terus menerus belajar dan memperoleh keunggulan dari pengetahuan yang di dapat sepanjang hidup.

pemberian motivasi oleh pimpinan kepada bawahan tidaklah begitu sukar, namun dalam praktiknya pemberian motivasi jauh lebih rumit. Siagian (2001) menjelaskan kerumitan ini disebabkan oleh:

1. Kebutuhan yang tidak sama pada setiap pegawai, dan berubah sepanjang waktu. Disamping itu perbedaan kebutuhan pada setiap taraf sangat mempersulit tindakan motivasi para manajer. Dimana sebagian besar para manajer yang ambisius, dan sangat termotivasi untuk memperoleh kepuasan dan status, sangat sukar untuk memahami bahwa tidak semua pegawai mempunyai kemampuan dan semangat seperti yang dia miliki, sehingga manajer tersebut menerapkan teori coba-coba untuk menggerakkan bawahannya.

2. Feeling dan emotions yaitu perasaan dan emosi. Seseorang manajer tidak memahami sikap dan kelakuan pegawainya, sehingga tidak ada pengertian terhadap tabiat dari perasaan, keharusan, dan emosi.

Aspek yang terdapat dalam diri pribadi pegawai itu sendiri seperti kepribadian, sikap, pengalaman, budaya, minat, harapan, keinginan, lingkungan yang turut mempengaruhi pribadi pegawai tersebut.

\section{KESIMPULAN}

Berdasarkan analisis data dan pengujian hipotesis yang telah dipaparkan pada Bab IV maka ditarik kesimpulan yaitu sebagai berikut:

1. Terdapat pengaruh yang positif dan signifikan Kompetensi, Kompensasi dan Motivasi secara simultan terhadap Kinerja Guru PNS bersertifikasi pada SMP Negeri 7 Palembang yang dibuktikan dengan nilai sig $\mathrm{F}$ sebesar $0,000<\alpha(0,05)$.

2. Terdapat pengaruh yang positif dan signifikan Kompetensi terhadap Kinerja Guru PNS bersertifikasi pada SMP Negeri 7 Palembang dengan nilai sig $\mathrm{t}$ sebesar $0,000<\alpha(0,05)$.

3. Terdapat pengaruh yang positif dan signifikan Kompensasi terhadap Kinerja Guru PNS bersertifikasi pada SMP Negeri 7 Palembang dengan nilai sig $\mathrm{t}$ sebesar $0,007<\alpha(0,05)$.

4. Terdapat pengaruh yang positif dan signifikan Motivasi terhadap Kinerja Guru PNS bersertifikasi pada SMP Negeri 7 Palembang dengan nilai sig t sebesar $0,049<\alpha$ $(0,05)$.

\section{SARAN}

Berdasarkan kesimpulan hasil penelitian seperti dipaparkan sebelumnya maka pada bagian berikut perlu diberikan beberapa saran pada pihak-pihak yang terkait dengan penelitian ini.

1. Bagi Guru PNS bersertifikasi pada SMP Negeri 7 Palembang, disarankan untuk lebih meningkatkan lagi Kinerja yang sudah berjalan baik sekarang ini, terutama indikator yang masih rendah yaitu; pada dimensi Kemampuan Kerja dan pada indikator; Kualitas Kerja disarankan untuk senantiasa berupaya meningkatkan kualitas kerja di SMP Negeri 7 Palembang

2. Bagi Kepala SMP Negeri 7 Palembang agar dapat lebih meningkatkan Kinerja Guru PNS bersertifikasi melalui Kompetensi, Kompensasi dan Motivasi yang sudah terlaksana saat ini :

3. Kompetensi, beberapa indikator yang masih rendah perlu dioptimalkan antara lain pada dimensi Keterampilan, pengalaman dan pada indikator; Menjalankan tugas, Mengadakan variasi dan Variasi tugas disarankan untuk berusaha menyelesaikan 
pekerjaan meskipun sulit, senang menerima gagasan baru agar menambah kompetensi dan melatih keterampilan saya bertambah baik.

4. Kompensasi, beberapa indikator yang masih rendah perlu dioptimalkan antara lain pada dimensi Insentif pegawai, Lama kerja, Kebutuhan dan Evaluasi jabatan; disarankan sekolah memberikan kompensasi atas kinerja yang telah dihasilkan oleh guru, Kompensasi yang diberikan oleh tempat saya bekerja tidak berdasarkan atas kemampuan guru dalam bekerja, Kompensasi yang diberikan sesuai dengan harapan guru, guru merasa terbantu atas pemberian kompensasi, sekolah memberikan kompensasi secara adil kepada guru, sekolah memberikan kompensasi yang layak kepada guru berdasarkan hasil evaluasi kerja guru dan Kompensasi guru tidak berbeda jauh mulai dari jabatan tingkat atas sampai jabatan tingkat bawah.

5. Motivasi, beberapa indikator yang masih rendah perlu dioptimalkan antara lain pada dimensi Adanya semangat yang tinggi untuk berprestasi, Mendapatkan kompensasi dan pada indikator; kedisiplinan, Komitmen, yaitu mengajar dengan penuh disiplin, semangat komitmen yang tinggi, mendengarkan ideide dari guru lainnya.

6. Bagi peneliti lain, untuk menindaklanjuti lebih jauh hasil penelitian ini dengan mengembangkan variabelvariabel bebas yang lain seperti; Disiplin kerja Guru dan Pengawasan Guru PNS bersertifikasi, sehingga dapat memberikan kontribusi bagi peningkatan Kinerja Guru PNS bersertifikasi pada SMP Negeri 7 Palembang.

\section{Implikasi}

Upaya untuk meningkatkan Kinerja Guru PNS bersertifikasi pada SMP Negeri 7 Palembang. dapat dilakukan dengan peningkatkan Kompetensi, Kompensasi dan Motivasi yang pada gilirannya dapat meningkatkan Kinerja yaitu:

1. Upaya meningkatkan Kinerja, seperti di tempat saya mengajar saat ini sarana penunjang sudah memadai, fasilitas kerja yang ada harus diperhatikan dengan sebaik-baiknya, peraturan yang dibuat di sekolah terlaksana dengan baik, saya selalu evaluasi hasil pekerjaan.

2. Upaya optimalisasi Kompetensi, seperti suka bekerja keras dalam menambah pengetahuan saya, berusaha meningkatkan pemahaman saya tentang tugas saya agar dapat maju, berusaha mengadakan variasi dalam menyelesaikan tugas dan memiliki masa kerja yang cukup untuk dapat menguasai beban tugas saya.

3. Upaya menerapkan Kompensasi, seperti sekolah telah memberikan kompensasi berdasarkan hasil kerja guru.

4. Upaya meningkatkan Motivasi, Saya merasa nyaman dengan ruangan kerja yang ada, memberikan pujian jika pekerjaan diselesaikan tepat waktu, saya mampu menggunakan fasilitas kerja untuk melaksanakan pekerjaan.

\section{DAFTAR PUSTAKA}

Ahmadi, Djauzak, 2004. "Peningkatan Mutu Pendidikan Sebagai Sarana Pembangunan Bangsa”, Jakarta: Balai Pustaka.

Alain Mitrain.2008. Human Resources and Personnel Management, Fifth Edition Mc. Graw-Hill Inc.
As'ari, A (2008). Representasi Pentingnya dalam Pembelajaran.UPI, Bandung

Bernadin and Russl, 2001, Human Resource Management. New York: Mc. Graw-Hill

Cowling \&James,2006. The Measurement of Work Performance: Methodes, Theory and Applications. London: Academic Press.

Dessler, Gary,2007. Human Resource Management. New Jersey: A Simon \& Schuster Company

Djamaludin, M. Arif. 2003. Persiapan Dan Seleksi dalam Manajemen Sumber Daya Manusia. Jakarta: Sekolah Tinggi Manajemen IMMI.

Emmons, Goerge T. and Albert W. Boudreau, 2001.Human Resource Management. Chicago: Rhicard D. Irwin.

Fisher, Robert, 2009, Organizational Communication. New Jersey: A Simon \& Schuster Company.

Foster, B. S., dan R. Karen, 2001, Pembinaan Untuk Meningkatkan Kinerja Karyawan, PPM Jakarta

Hadari, Nawawi, 2000. Manajemen Sumber Daya Manusia untuk Bisnis yang Kompetitif. Yogyakarta: Gajah Mada University

Haidir, 2004.Kualitas Pelayan dan Iklim Kerja dalam Meningkatkan Kinerja, Jakarta.

Husein, Umar.2009, Strategic Management in Action.PT. Gramedia Pustaka Utama. Jakarta

Widodo, J.2001, Manajemen Personalia, CV. Akademik Pustaka, Jakarta.

Kamaluddin. 2006. Aspek Pembangunan Nasional dan Daerah, Ghalia Indonesia, Jakarta.

Koentjaraningrat.2003. Metode-metode Penelitian Masyarakat ed. Ketiga. Jakarta: PT. Gramedia.

Koontz, H., C. O'Donnell, dan H. Wehrich, 2006, Manajemen, Jilid 2, Terjemahan, Erlangga, Jakarta.

Malayu SP. Hasibuan, 2000, Manajemen Sumber Daya Manusia, Edisi Revisi, Bumi Aksara, Jakarta.

Mulia Nasution,2006. Manajemen Sumber Daya Manusia Perusahaan, Penerbit PT. Remaja Rosdakarya, Bandung.

Moenir, A.S,2009. Pendekatan Manusia dan Organisasi Terhadap Pembinaan Kepegawaian, Jakarta: CV. Haji Masagung

Notoadmojo, Soekidjo, 2003, Pengembangan Sumber Daya Manusia. Jakarta: Rineka Cipta.

Ruky, Achmad S. 2001. Sistem Manajemen Kinerja, Cetakan pertama. Jakarta: Gramedia.

Robbin P. Stephen, 2001, Perilaku Organisasi, Konsep, Kontrovers dan Aplikasi, Edisi Indonesia, Penerbit Prenhallindo, Jakarta.

Simamora, H. 2003. Manajemen Sumber Daya Manusia. STIE YKPN. Jakarta.

Steers (Magdalena, 2007) \& Hersey, P. \& Blanchard H.K. 2008. Manajemen Perilaku Organisasi: Pendayagunaan Sumber Daya Manusia, Penerjemah Agus Dharma, SH, med, Penerbit Erlangga, Jakarta.

Suradinata. 2007. Manajemen Sumber Daya Manusia, Cetakan Ketujuh. Bumi Aksara, Jakarta.

Susilo Martoyo,2004. Manajemen Personalia, CV. Akademi Pustaka, Jakarta. 
Sedarmayanti, 2001.Sumber Daya Manusia dan Produktivitas Kerja. Mandar Maju. Bandung

Siagian Sondang P. 2002. Organisasi Kepemimpinan dan Perilaku Administrasi. Gunung Agung. Jakarta

Siswoyo Haryono, 2007, Panduan Keberhasilan Menulis Tesis, MM-UTP Palembang.

Soeprihanto. 2008. Penilain Kinerja dan Pengambangan Karyawan. Yogyakarta: Andi Offset.
Soekijo Nomoatmojo, 2008. Manajemen dan Pengalaman Kerja. Balai Aksara. Jakarta.

Sulbahri Madjir dkk, 2013.Pedoman Penulisan Tesis, Unsri Press, Palembang.

Sugiyono, 2003. Metode Penelitian Bisnis. Bandung: CV Alfabeta 